\title{
Paleoclimate, ecoregion size, and degree of isolation explain regional biodiversity differences among terrestrial vertebrates within the Congo Basin
}

\author{
Frederik Van de Perre ${ }^{1, *}$, Herwig Leirs ${ }^{1} \&$ Erik Verheyen ${ }^{1,2}$ \\ ${ }^{1}$ Evolutionary Ecology Group - University of Antwerp, 2020 Antwerp, Belgium. \\ ${ }^{2}$ Royal Belgian Institute of Natural Sciences, OD Taxonomy and Phylogeny, 1000 Brussels, Belgium. \\ * Corresponding author: frederik.vandeperre@uantwerpen.be
}

\begin{abstract}
One of the most widely recognized patterns in ecology is the increase in species richness from poles to tropics. Literature suggests that the Congolian lowland rainforest does not follow this pattern: the Central Congolian forest (CCLF), south of the Congo River, is thought to harbor fewer vertebrate species and endemics than the Northeastern (NELF) and Northwestern lowland rainforests (NWLF) north of the Congo River. We used data from the Global Biodiversity Information Facility (GBIF) database on terrestrial vertebrates (mammals, birds, and reptiles), to test whether differences in sampling effort caused the irregular biodiversity pattern in this region. Our results show that even though the diversity within the Congolian lowland rainforests remains to be fully mapped, current differences in richness are unlikely to be caused by undersampling alone. We argue that the lower vertebrate richness in the CCLF is due to both its relatively small size and isolated position: Forest cover fluctuated throughout the history of the Congo Basin due to climatic variability, reducing speciation and increasing extinction, while immigration towards the CCLF is limited due to the barrier effect of the Congo River. The implications of these findings are discussed in the context of both fundamental ecology and conservation management.
\end{abstract}

Key words. Biodiversity, rainforest, conservation, refuge theory, species accumulation curves.

VAN De PerRe F., Leirs H. \& Verheyen E. (2019). Paleoclimate, ecoregion size, and degree of isolation explain regional biodiversity differences among terrestrial vertebrates within the Congo Basin. Belgian Journal of Zoology 149 (1): 23-42. https://doi.org/10.26496/bjz.2019.28

\section{Introduction}

One of the most widely recognized patterns in ecology is the increase in species richness from poles to tropics (WILLIG et al. 2003). Increased area, energy, time, climate stability, and temperature in the tropics are thought to be the drivers of the latitudinal gradient (FINE 2015). Within the tropics elevation is a major determinant of species richness (GRYTNES \& MCCAIN 2007). The patterns in species richness within the Congolian lowland rainforest seem to be the exception to these general patterns. Within the Congo Basin lowland rainforests, three ecoregions are identified based on faunal and floristic species richness and endemism (OLSON et al. 2001): the Central Congolian lowland rainforest (CCLF) south of the Congo River, and the Northeastern (NELF) and Northwestern lowland rainforests (NWLF) north of the Congo River (Fig. 1). The CCLF is thought to harbor lower vertebrate species richness and 
endemism compared to the northern lowland forests (COLYN et al. 1991; BROOKS et al. 2001; DE KLERK et al. 2002). Species richness maps based on range maps show that the CCLF has lower levels of richness, for all vertebrate groups, than all other Afrotropical rainforest ecoregions (OLSON et al. 2001; LEWIN et al. 2016).

However, the observed diversity differences could be artificial. First of all, the accuracy of species richness estimates depends on sampling effort, and diversity data for the Congo Basin are known to be incomplete (GIBSON et al. 2011; PHILLIPS et al. 2017). Distribution maps for species based on a limited number of verified occurrences can be misleading (HERNANDEZ et al. 2006), making richness patterns based on stacked range maps potentially unreliable. To control for the dependency of species richness on sample size, we can compare sampling curves (GOTELLI \& COLWELL 2001) and correct for sample completeness (CHAO \& JOST 2012). The sampling curve shows the accumulation of species richness with increased sample size. The sample completeness is the inverse of the slope of the accumulation curve, meaning that when the sampling curve reaches an asymptote, the sample completeness is $100 \%$ (CHAO \& JOST 2012). However, comparing the sampling effort based on sampling curves assumes samples were obtained randomly (GOTELLI \& COLWELL 2001). Within ecoregions, this depends on the spatial distribution of sampling sites (REDDY \& DÁVALOS 2003). Secondly, all species that have part of their range within the ecoregion will be considered present throughout the ecoregion, regardless of the proportion of overlap. However, if species richness differences are due to environmental conditions then only species that thrive in the studied environment should be considered. The assessment of species richness levels in the Congo Basin is important to determine conservation strategies (ANTHONY et al.

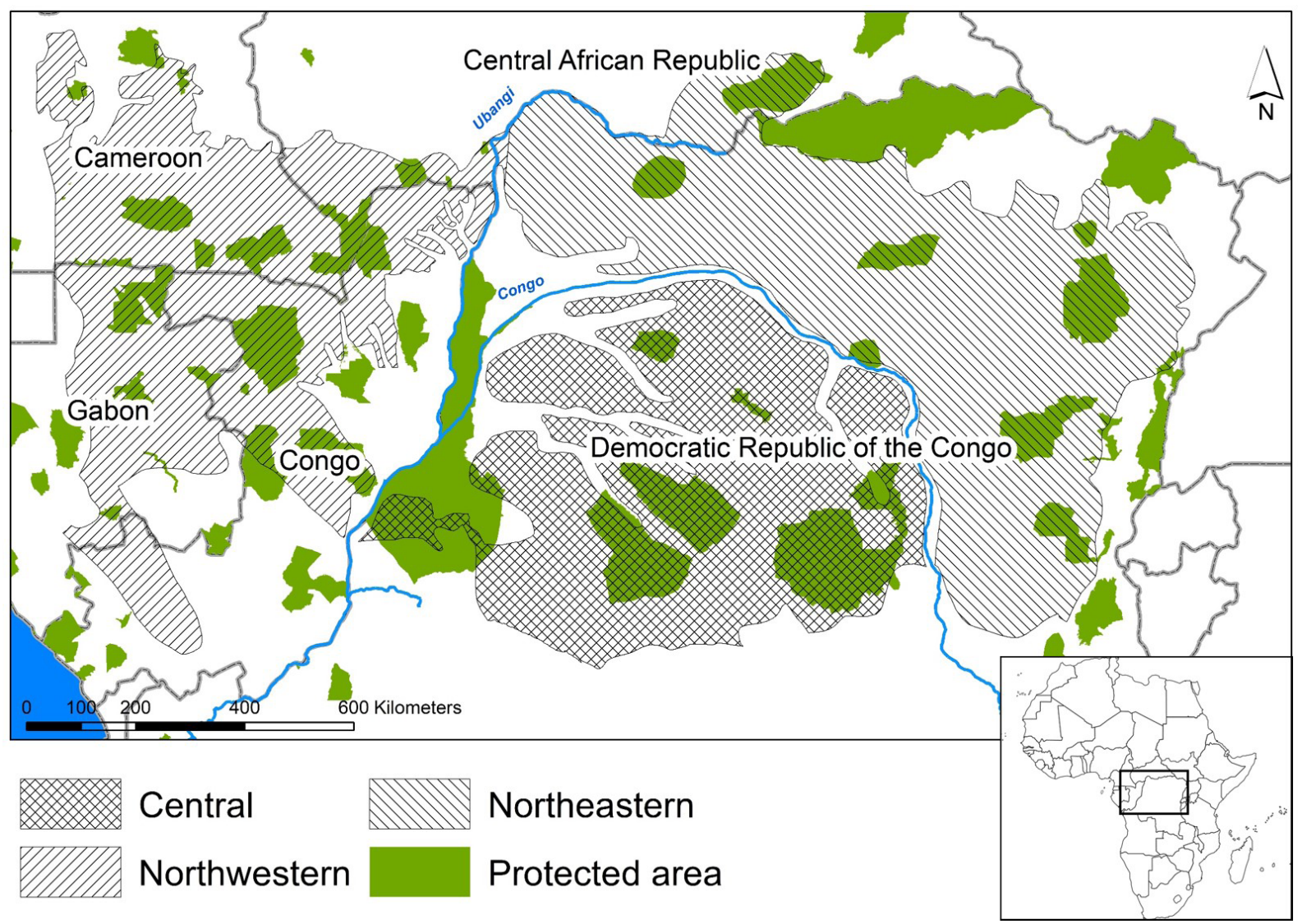

Fig. 1 - Map of the Congo basin lowland forest ecoregions (which stretch over Cameroon, DR Congo, Congo, Central African Republic, and Gabon), including the location of protected areas and rivers separating the ecoregions. 
2015): which species are undersampled; which areas remain unknown; and how are differences in regional species richness reflected in protected areas?

If undersampling alone would not explain species richness differences among ecoregions, this would indicate differences in large-scale drivers of speciation and extinction between ecoregions (FINE 2015). In the Congo Basin, speciation and extinction rates were catalyzed by climatic fluctuations and its geological history. Environmental theories of African faunal evolution state that important evolutionary changes during the Pliocene-Pleistocene interval (the last ca 5.3 million years) were mediated by changes in African climate or shifts in climate variability. Marine sediment sequences demonstrate that subtropical African climate periodically oscillated between markedly wetter and drier conditions, paced by earth orbital variations, with evidence for step-like ( $\pm 0.2 \mathrm{Ma})$ increases in African climate variability and aridity near $2.8 \mathrm{Ma}, 1.7 \mathrm{Ma}$ and $1.0 \mathrm{Ma}$, coincident with the onset and intensification of high-latitude glacial cycles (DEMENOCAL 2004). Due to these climatic fluctuations the Congo Basin rainforest has retracted and re-expanded several times over the past million years (MALEY 1996; PLANA 2004; MALEY et al. 2018). In dry periods lowland rainforests became refugia where forest-dependent animals were able to persist until more favorable conditions (i.e., wetter and warmer) allowed them to re-expand their ranges (PLANA 2004). The Pleistocene refuge hypothesis postulates that forest fragmentation led to the isolation and subsequent divergence of forest-associated taxa (COLYN et al. 1991). At the same time, glacial maxima would often have meant large numbers of local extinctions (PLANA 2004). Indeed, the lower alpha diversity in African rainforest trees compared to Amazonia could be linked to the lower number of species adapted to warm wet climate, which could in turn be linked to higher extinction rates due to environmental instability (PARMENTIER et al. 2007).

The Congo River as we know it today originated 3.5MYA when geological activity freed the island lake in the center of the Congo Basin to flow into the Atlantic Ocean (MYERS THOMPSON 2003). Although the location of the Congo River has changed over the course of millions of years, it has presented a transcontinental water barrier to dispersal for the past 34 million years (ТАКЕМОТО et al. 2015). The riverine barrier hypothesis suggests that isolation of species' populations on both sides of the rivers led to allopatric speciation (COLYN et al. 1991). The Congo River is known to be a distribution barrier for several monkey (COLYN et al. 1991; HARCOURT \& WOOD 2012), ape (ERIKSSON et al. 2004; TAKEMOTO et al. 2015), rodent (KATUALA et al. 2008; KeNNIS et al. 2011), and bird species (LOUETTE 1992). Nevertheless, rivers were probably shrunken during arid periods and presented less effective barriers to gene flow (ANTHONY et al. 2007; KENNIS et al. 2011; TAKEMOTO et al. 2015). Therefore, the Pleistocene refuge and river barrier hypotheses are not necessarily mutually exclusive; taxa historically segregated in refugia were limited by river barriers in their re-expansion during humid conditions (HUNTLEY \& VOELKER 2016).

Here, we (1) show that diversity differences between ecoregions in three terrestrial vertebrate groups based on occurrences from GBIF cannot be explained by differential sampling effort; and (2) argue that the climatic and geological history of the Congo Basin rainforest can drive differences in species richness and (3) discuss the implications for biodiversity conservation in the region.

\section{Material and methods}

Our study area includes all Congolian lowland forest ecoregions as defined by OLSON et al. (2001): the Central Congolian lowland rainforest (CCLF), and the Northeastern (NELF) and Northwestern lowland rainforests (NWLF) (Fig. 1). Ecoregions are defined as relatively large units of land containing a distinct assemblage of natural communities and species, with boundaries that approximate the original extent of natural communities prior to major land-use change (OLSON et al. 2001). The CCLF, NELF, and NWLF belong to the biome of tropical and subtropical moist broadleaf forests of the Afrotropical realm. The northern, eastern and western limits of the CCLF are bound by the Congo River and swamp forest, while 
in the south there is a gradual transition to savanna-forest mosaic (BLOM 2019a). The NELF is located in the northeastern portion of the Democratic Republic of Congo (DRC) and extends into the Southeastern portion of the Central African Republic (CAR). The northern margin is fixed by the transition to savanna and woodland habitats, the eastern border is bounded by the Albertine Rift Montane Forests, and the southern and western margins are delimited by the Congo River and its tributaries, primarily the Elila River (BLOM \& SCHIPPER 2019). The NWLF stretches across four countries - Cameroon, Gabon, Republic of Congo, and the CAR. It is bordered to the north and south by forest-savanna mosaics and to the east by swamp forest and the Ubangi river, while the western limit grades gradually into the lowland rainforests of the Atlantic Equatorial Coastal Forests ecoregion (BLOM 2019b).

We compared occurrence records for mammals, birds, and reptiles in the Global Biodiversity Information Facility (GBIF) database queried on $2^{\text {nd }}$ October 2018 - to assess the sampling coverage in each ecoregion. All occurrences lying within the boundaries of each ecoregion were exported using the rgbif package (CHAMBERLAIN et al. 2018) in R3.1 (R Core Team 2017). We only used records from extant taxa that were identified up to the species (or subspecies) level. Records originating from countries that are not part of our study area were considered to have incorrect coordinates and were removed from our dataset. As GBIF is an international network that collects species occurrence records from its participants, it currently does not include all available occurrences. We calculated the number of occurrences for each quarter-degree grid cell in ArcGIS 9.3 (ESRI 2008) to assess the location and intensity of collecting for each species group. To assess the number of species missing from GBIF, we retrieved presence/absence data for reptiles, birds, and mammals, for each of the three terrestrial ecoregions from the WWF WildFinder database (WORLD WILDLIFE FUND 2006). As the WWF data were gathered from numerous scientific works, field guides, or directly from experts, the database offers a comprehensive list of species. To ensure consistency in taxonomy, species names were matched with IUCN nomenclature (IUCN 2018) using the redlist package (CHAMBERLAIN \& SALMON 2018).

The number of occurrences per species was used to create sampling curves for each species group and for each ecoregion. Sample completeness, the proportion of the total number of individuals in a community that belong to the species represented in the sample, was calculated using the iNEXT package in R (HsIEH et al. 2016). We compared species richness at equal sample completeness, using for each species group the lowest sample completeness of all ecoregions. Non-overlapping $95 \%$ confidence intervals indicate significant differences at a level of 5\% between ecoregions (CHAO et al. 2014).

Apart from analyzing all species within each database (the complete dataset), a second analysis included only those species that are known to thrive within the habitats of the studied ecoregions (habitat dataset). To ensure that we only included species that are known to frequently occur in the ecoregions' habitats, we only included those species for which (sub)tropical moist lowland and swamp forest (Habitats 1.6 and 1.8) are suitable habitat according to the IUCN Red list (IUCN 2018). This analysis was only possible for birds and mammals as the Global Reptile Assessment is still underway.

To assess the relative isolation of each ecoregion and the effects of the Congo and Ubangi rivers as faunal barriers, we determined similarities in terms of species composition using the adjusted Jaccard similarity index. We determined similarities between the northern (both NELF and NWLF) versus the central (CCLF) ecoregions to test for the effect of the Congo River, and between the western (NWLF) versus eastern (NELF) ecoregions to test for the effect of the Ubangi river. The classic Jaccard index of compositional similarity $\left[\mathrm{S}_{12} / \mathrm{S}_{1}+\mathrm{S}_{2}\right]$ (and other indices that depend upon the same variables) are notoriously sensitive to sample size, especially for assemblages with numerous rare species (CHAO et al. 2005, 2006). We therefore used an estimator for this index that includes the effect of unseen shared species, based on abundance-based sample data (CHAO et al. 2005, 2006). The adjusted Jaccard index was calculated using the SpadeR package (CHAO et al. 2015). 
TABLE 1

(a) Number of occurrences and species, sample completeness, and GBIF completeness for three terrestrial vertebrate groups within the three ecoregions based on the complete and habitat dataset. (b) Total surface area and protected area of each ecoregion.

\begin{tabular}{|c|c|c|c|c|c|c|}
\hline \multirow[t]{2}{*}{ (a) } & \multicolumn{2}{|c|}{ CCLF } & \multicolumn{2}{|c|}{ NELF } & \multicolumn{2}{|c|}{ NWLF } \\
\hline & Complete & Habitat & Complete & Habitat & Complete & Habitat \\
\hline \multicolumn{7}{|l|}{ Mammals } \\
\hline Number of occurrences & 3556 & 3262 & 19403 & 17547 & 5534 & 5006 \\
\hline Number of species & 82 & 69 & 224 & 171 & 180 & 154 \\
\hline Sample completeness & $99.3 \%$ & $99.4 \%$ & $99.8 \%$ & $99.9 \%$ & $99.2 \%$ & $99.5 \%$ \\
\hline GBIF completeness & $71.9 \%$ & $67.6 \%$ & $113.1 \%$ & $103.0 \%$ & $94.7 \%$ & $90.6 \%$ \\
\hline \multicolumn{7}{|l|}{ Birds } \\
\hline Number of occurrences & 768 & 601 & 15704 & 13964 & 7245 & 6177 \\
\hline Number of species & 253 & 185 & 652 & 403 & 511 & 335 \\
\hline Sample completeness & $85.7 \%$ & $88.0 \%$ & $99.3 \%$ & $99.7 \%$ & $98.7 \%$ & $99.4 \%$ \\
\hline GBIF completeness & $74.0 \%$ & $75.5 \%$ & $118.3 \%$ & $115.1 \%$ & $97.9 \%$ & $97.4 \%$ \\
\hline \multicolumn{7}{|l|}{ Reptiles } \\
\hline Number of occurrences & 43 & & 431 & & 492 & \\
\hline Number of species & 19 & & 104 & & 94 & \\
\hline Sample completeness & $70.0 \%$ & & $91.7 \%$ & & $93.5 \%$ & \\
\hline GBIF completeness & $24.7 \%$ & & $88.9 \%$ & & $76.4 \%$ & \\
\hline (b) & \multicolumn{2}{|c|}{ CCLF } & \multicolumn{2}{|c|}{ NELF } & \multicolumn{2}{|c|}{ NWLF } \\
\hline \multicolumn{7}{|l|}{ Surface area } \\
\hline Ecoregion $\left(\mathrm{km}^{2}\right)$ & \multicolumn{2}{|c|}{412,882} & \multicolumn{2}{|c|}{535,865} & \multicolumn{2}{|c|}{432,190} \\
\hline Protected area $\left(\mathrm{km}^{2}\right)$ & \multicolumn{2}{|c|}{90,471} & \multicolumn{2}{|c|}{60,759} & \multicolumn{2}{|c|}{69,317} \\
\hline Proportion protected & \multicolumn{2}{|c|}{$21.1 \%$} & \multicolumn{2}{|c|}{$11.3 \%$} & \multicolumn{2}{|c|}{$16.0 \%$} \\
\hline
\end{tabular}

We determined the area of each ecoregion that is under some level of protection, by intersecting the protected areas with known extent (UNEP-WCMC and IUCN 2018) with each ecoregion.

\section{Results}

The number of occurrences is consistently lower in the CCLF compared to the NELF and NWLF, especially for birds and reptiles (Table 1a), indicating that the sampling effort is lower in the CCLF. The sampling completeness indicates that species inventories in all three ecoregions are incomplete. More importantly, the sample completeness differs between ecoregions and is markedly lower in the CCLF for reptiles and birds. The location of collection largely depends on the accessibility, with most occurrences clustered along rivers in all ecoregions (Fig. S1). Higher intensities are noted along the eastern border of the NELF and major cities such as Kisangani. The spatial collection bias towards accessible locations (e.g., along the rivers or close to major cities) is similar in all ecoregions, and we therefore assume that the associated underestimation of species richness would be similar (REDDY \& DÁvALOS 2003). Largest differences in species richness between the, more complete, WWF database and the GBIF dataset are found for reptiles (Fig. 2 and Tables 1a, S1, S2, and S3). Between ecoregions the CCLF shows largest differences between databases, while GBIF contains more bird and mammals species than GBIF in the NELF. 


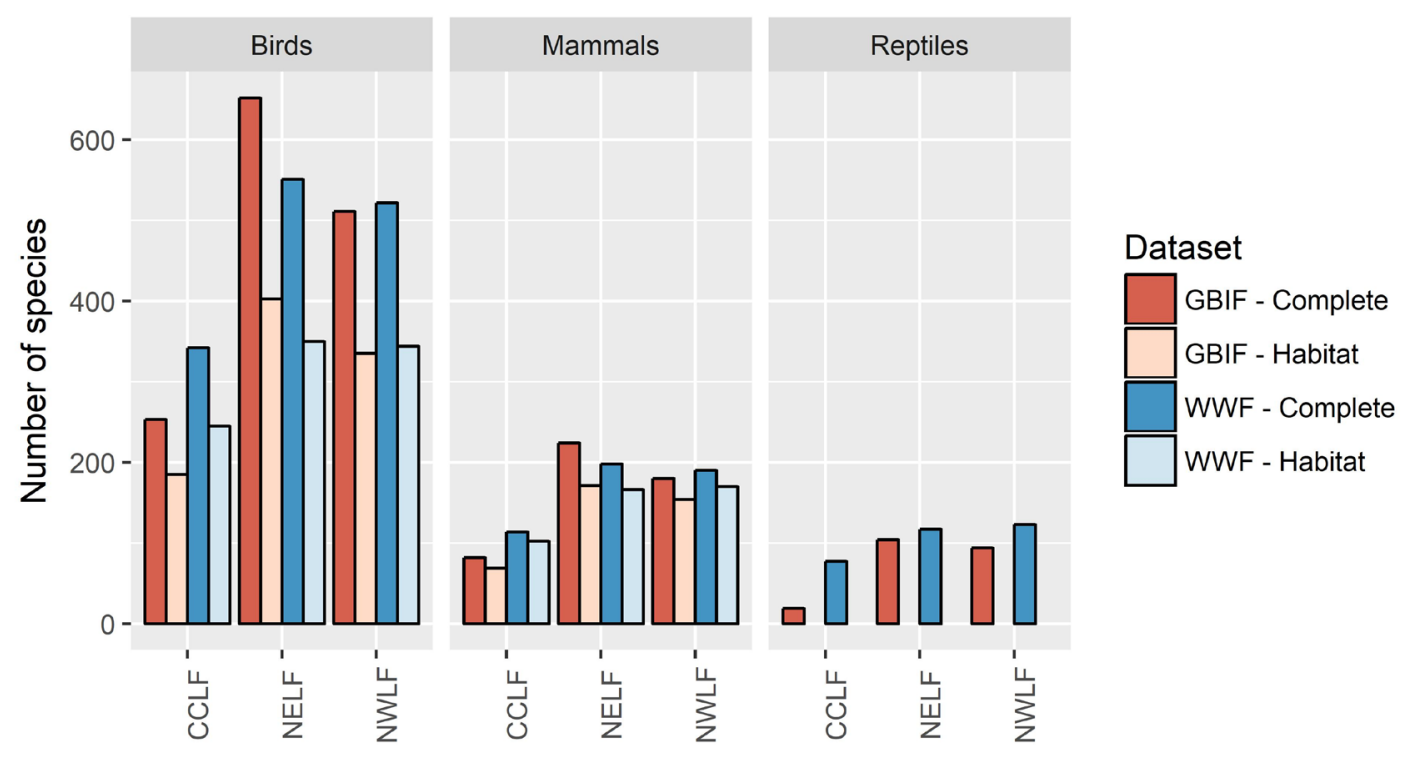

Fig. 2 - Number of species in each ecoregion based on the GBIF or WWF dataset using all available species or only those with specified habitat requirements.

When standardized for sample completeness, species richness of mammals, birds, and reptiles is significantly lower in the CCLF compared to the NELF and NWLF (Figs 3-4). The NELF is the most speciose ecoregion for birds and reptiles, while for mammals the NELF and NWLF are equally speciose. The same conclusions apply when only species with specified habitat requirements were included. The observed number of species within the habitat dataset is lowest in the CCLF based on both the GBIF and WWF dataset (Fig.2). When standardized for sample completeness the habitat dataset showed similar patterns to the complete dataset.

The adjusted Jaccard index shows that the species compositions of the NWLF and NELF are more similar than the species composition of the CCLF compared to the northern ecoregions. Furthermore, similarity decreases from birds to mammals to reptiles (Fig. 5). As the habitat dataset only includes species with equal habitat requirements, compositional similarity will generally be higher based on the habitat dataset than on the complete dataset.

The proportion of area protected is inversely correlated to the ecoregion size (Table $1 \mathrm{~b}$ ).
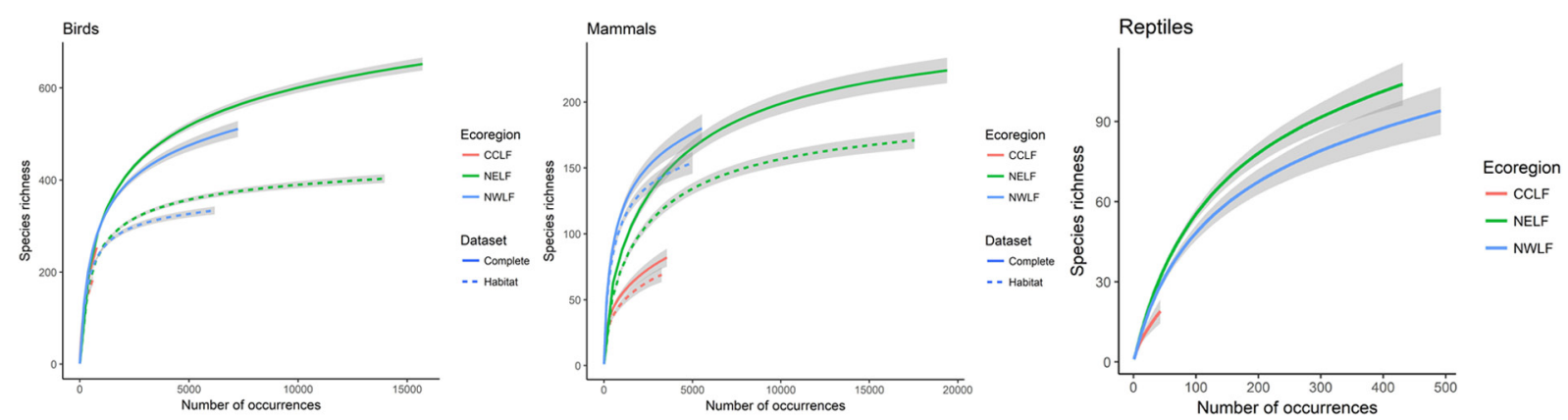

Fig. 3 - Sampling curves for mammals, birds, and reptiles based on the complete and habitat datasets in each of the three ecoregions. Non-overlapping confidence intervals indicate significant differences in species richness. 


\section{Discussion}

Our analyses show that species inventories of the Congo Basin lowland forest ecoregions are incomplete, but that undersampling alone does not explain the differences in species richness between these ecoregions. Both the complete and habitat datasets derived from the GBIF database show that observed and standardized species richness are significantly lower in the CCLF, compared to the NELF and NWLF. We used the GBIF dataset as it is the largest database with sampling records, allowing us to assess sampling completeness. However, the GBIF database does not necessarily include all known species from the region. The GBIF database contains notably less species than WWF database in the CCLF and to a lesser extent the NWLF. Especially reptiles are underrepresented in the GBIF database. On the other hand, the GBIF dataset contains more mammal and bird species than does the WWF database for the NELF, and some entire reptile families are not included in the WWF database (Table S3). This shows that even databases that are considered comprehensive such as WWF Wildfinder do not contain all species occurring in the Congo Basin. Indeed, a comprehensive literature study on reptiles yielded considerably more species in each of the ecoregions: 150 species in the CCLF, 241 in the NWLF and 249 in the NELF (LEWIN et al. 2016). Nevertheless, studies that attempted to use all available data show similarly large differences between the CCLF and the northern ecoregions, NELF and NWLF (BROOKS et al. 2001; LEWIN et al. 2016). Controlling for habitat requirements ensures that analyzed species are effectively dependent on the habitats that determine the outline of the ecoregions. In this way occasional savanna species or overflying vagrants can be excluded from analysis. Indeed, many of the excluded species were only found once (singletons), which explains the higher sample completeness in the habitat dataset. Even though our selection criteria are conservative (only two habitat types) and the true amount of lowland forest dependent species will likely be higher, the observed richness of the NELF and NWLF based on the habitat dataset is never higher than the species richness of the CCLF based on the complete dataset (Table 1a).

As we limited our assessment to Congolian lowland rainforests, observed diversity differences among ecoregions cannot be explained by current ecological drivers: productivity, energy, or climate are likely

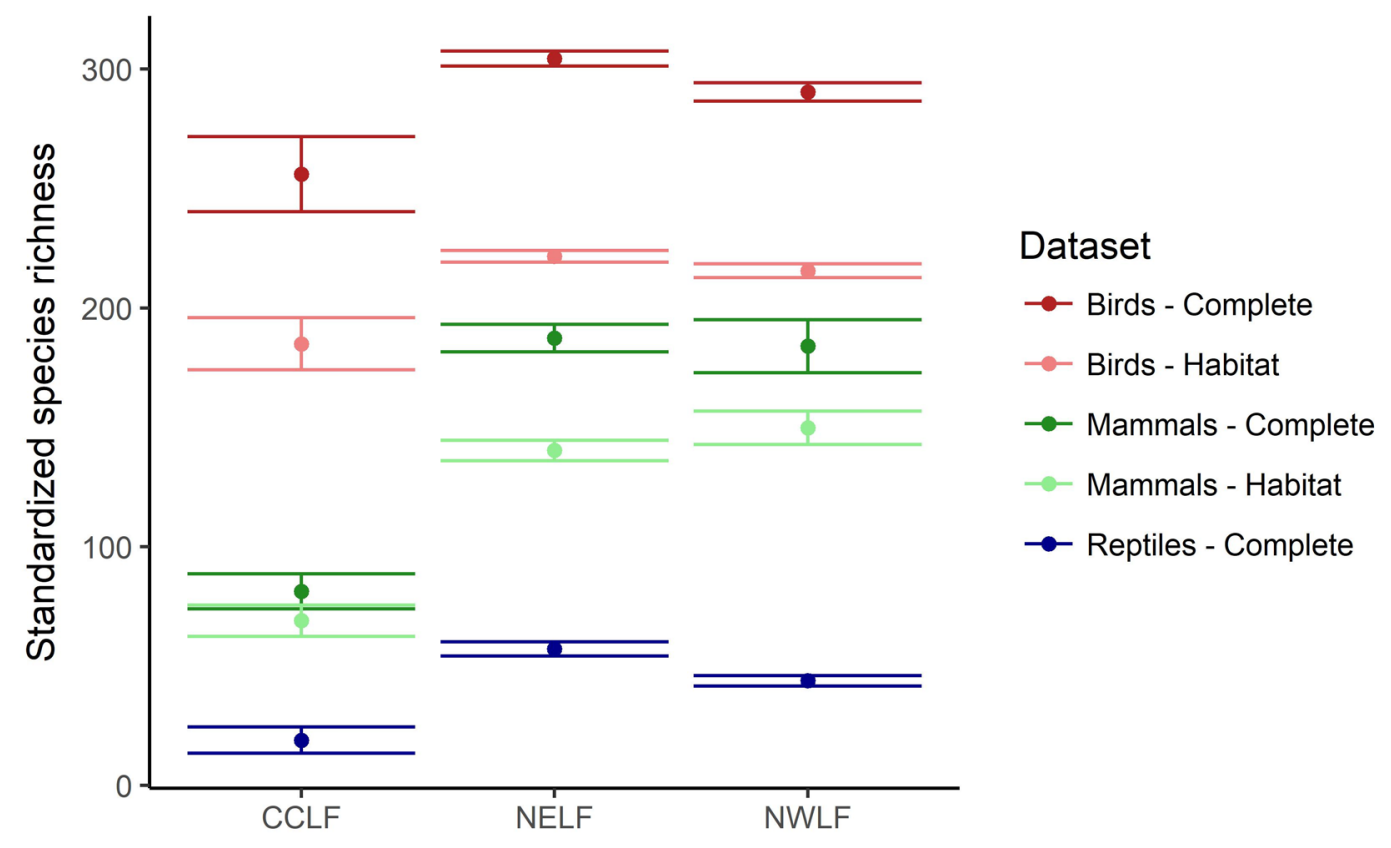

Fig. 4 - Species richness standardized for sample completeness (with 95\% confidence interval) was lowest in the CCLF for all species groups, and in both the complete and habitat datasets. 
to be similar among the studied ecoregions (PEEL et al. 2007; SAATCHI et al. 2011; FAYOLLE et al. 2014). However, the studied ecoregions do differ in topographic complexity: the NELF declines in elevation from east to west, from the Albertine Rift Mountains towards the Congo River (BLOM \& SCHIPPER 2019), the central portion of the CCLF is low-lying while hills up to 700-800 $\mathrm{m}$ are found in the south (BLOM 2019a), and NWLF has a more uniform relief (BLOM 2019b). As our results suggest that both NELF and NWLF are significantly more speciose than the CCLF, topographic complexity alone cannot explain these differences. Instead, we argue that the differences in speciation and extinction rates are provoked by climatic fluctuations and associated forest area fluctuations throughout the history of the Congo Basin, while the isolation and relatively small area of the CCLF ultimately led to lower speciation and immigration, and higher extinction.

The lower species richness of the CCLF could be due to its relatively small size. In general, larger ecoregions have on average larger-ranged species, which translates into higher speciation rates (presuming larger ranges lead to higher probabilities of allopatric speciation) and lower extinction probabilities (presuming larger ranges have lower probabilities of extinction) (GASTON 2000; FINE 2015). In Africa, current ecoregion size explains a substantial proportion of the variation in richness of reptiles (LEWIN et al. 2016). Evidence can also be found in species' demographics. For instance, based on population genetics, central and eastern Chimpanzee (Pan troglodytes) subspecies (occurring north of the Congo River) were inferred to have expanded tenfold between around 50,000 and 80,000 years ago and today, while the population size of the neighboring Bonobo (Pan paniscus; occurring in the Central rainforests) remained constant (HVILSOM et al. 2014). The effect of ecoregion size was likely exacerbated in glacial maxima when lowland rainforest retracted into forest refugia. Indeed, historical habitat area is often a better predictor for species richness than current habitat area (JETZ \& FINE 2012). CHAPMAN (1983) noted a slight correlation between the number of tropical rainforest primate species in a refugium today and the estimated area of the rainforest refugia during the last glacial maximum.

Still, compared to the CCLF the similar-sized NWLF hosts significantly higher numbers of species. This can be explained by the larger barrier effect of the Congo River compared to its tributaries (e.g., the Ubangi river) which form the border between the northern ecoregions. Indeed, there is a higher similarity in terms of species composition between the NWLF and NELF than between the CCLF and both northern ecoregions (Fig. 5). The barrier effect of the Congo River is reflected in the evolutionary history of some forest-associated species. Historical east-west movement was recorded in both the Gorilla genus (ANTHONY et al. 2007) and Chlorocebus lhoesti species group (TOSI 2008). These primates currently occur in the east and west of the Congolian forest, implying that they were able to cross large rivers north of the Congo River but never established sustainable populations south of the Congo River. Bonobos only branched off from other Pan clades during an arid period in the middle Pleistocene when its common ancestor was able to cross the Congo River (TAKEMOTO et al. 2015). A species of Cricetomys occurring south of the Congo River was found to be more closely related to a savanna species occurring south of the rainforest than to rainforest species north of the river (OLAYEMI et al. 2012). The combined effect of the smaller habitat area and isolated position of the CCLF compared to the northern ecoregions led to lower speciation, higher extinction, and lower immigration resulting in lower levels of richness and endemism within the CCLF.

The effect of habitat area and isolation on speciation, extinction and immigration will be most pronounced for species with high habitat affinity and low dispersal capacities. Indeed, evidence for the Pleistocene refuge and the riverine barrier hypotheses was mostly found in less mobile taxa (NICOLAS et al. 2005; KENNIS et al. 2011; JACQUET et al. 2014), while more mobile taxa originated well before the Pleistocene and were merely conserved in forest refugia (FJELDSA \& LOVETT 1997). Even within species groups, the barrier effect of the Congo River is not uniform among taxa. For instance, most rodent (KENNIS et al. 2011) and shrew (GAMBALEMOKE et al. 2008) species are limited to one side of the Congo with exceptions occurring on both banks, while few bat (HASSANIN et al. 2015, 2018) and 
bird species (HUNTLEY \& VOeLKeR 2016), occur on only one side of the Congo River. If richness is limited by habitat area and isolation, this implies that diversity differences among Congolian lowland forests are mostly due to forest-associated taxa with limited dispersal capacities. Indeed, historical habitat stability is more likely to explain patterns of species richness in species with limited dispersal capacities (GRAHAM et al. 2006) or limited ecological flexibility (RowAN et al. 2016). Our study shows that differences between the CCLF and northern ecoregions in species richness are most pronounced for mammals (Fig. 4) while compositional similarity is highest for birds (Fig. 5).

We demonstrated that species inventories for three large vertebrate groups are incomplete and that diversity differences between Congolian lowland forests are likely caused by forest-associated taxa with low dispersal abilities. This has several implications for biodiversity conservation in the region. First, successful conservation of biodiversity depends, in part, upon an accurate assessment of the diversity to be preserved. Given current and future threats to biodiversity in the Congolian lowland forests (ABERNETHY et al. 2013; TYUKAVINA et al. 2018), increased effort to survey its biodiversity is required. Our study confirms incomplete sampling for all three vertebrate groups (with reptiles holding largest deficits), but this situation is also true for plants (LOVETT et al. 2000; BROOKS et al. 2001; PARMENTIER et al. 2007). Second, the proportion of area protected within each ecoregion remains limited: the NELF and NWLF do not reach the Aichi Biodiversity Target 11 (CBD 2011) of 17\%. Even though the NELF hosts the highest number of species within the Congolian lowland forests and is considered a conservation priority area (BROOKS et al. 2001), it has the lowest proportion of area protected within the Congo Basin (Table 1). Knowing that within the NELF there is a whole cohort of bird species with very small restricted ranges (HALL \& MOREAU 1970) and the ranges of many threatened species currently fall outside protection (DE KLERK et al. 2004), there is an urgent need for more protected area within the Congolian lowland forest, particularly the NELF. Lastly, the lower species richness in the CCLF is contradictory to ecological theory, as areas with higher levels of energy-related variables such as primary productivity, potential evapotranspiration, solar radiation, temperature, and rainfall tend to have higher species richness (BROOKS et al. 2001; LEWIN et al. 2016). This means the CCLF can be considered a

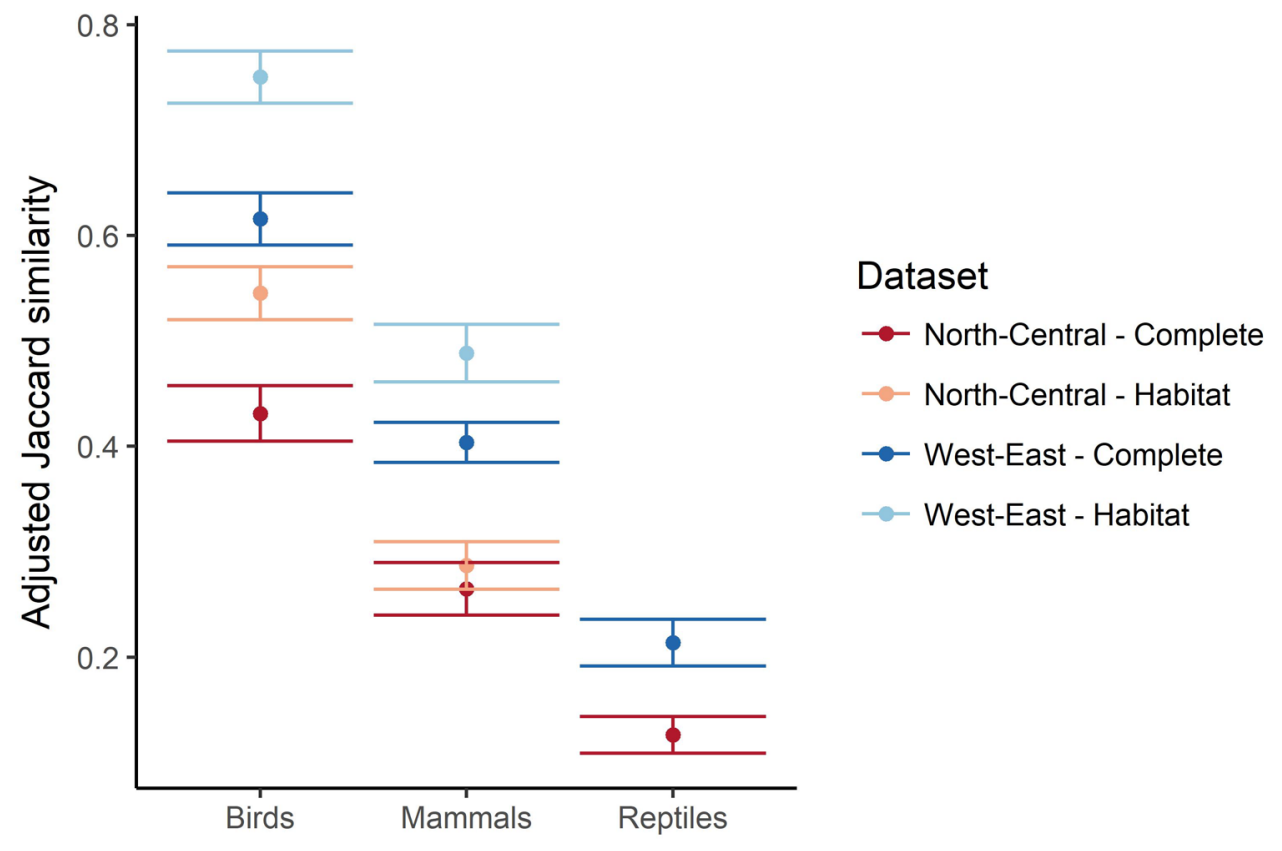

Fig. 5 - Similarity $( \pm$ SE) in terms of species composition between the northern (NELF and NWLF) is higher than similarity between the central (CCLF) ecoregion and NWLF and NELF for all species groups, and in both the complete and habitat datasets. 
diversity anomaly (after RICKLEFS 2006). Diversity anomalies are usually identified on a global extent (e.g., RICKLEFS et al. 2006; SWENSON et al. 2016), so to our knowledge the richness differences between the Congolian lowland forest ecoregions would represent the first anomaly on a regional scale. This means that an increased effort to study the biodiversity within the Congo Basin would not only facilitate conservation measures, but will also contribute to fundamental research in determining, for example, how the differences in regional species richness influence ecosystem functioning or local diversity.

\section{Acknowledgements}

This study is a reportable component of the COBIMFO Project (Congo Basin integrated monitoring for forest carbon mitigation and biodiversity; contract no. SD/AR/01A) and was funded by the Belgian Science Policy Office (Belspo). F.V.d.P. was supported by a Ph.D. fellowship from the Research FoundationFlanders. Thanks to A. Heughebaert for assistance in exporting GBIF data. We thank R. Van Damme, M. Colyn and two anonymous referees for useful comments on earlier versions of this manuscript.

\section{References}

Abernethy K.A., CoAd L., TAylor G., Lee M.E. \& Maisels F. (2013). Extent and ecological consequences of hunting in Central African rainforests in the twenty-first century. Philosophical Transactions of the Royal Society B: Biological Sciences 368: 20120303.

https://doi.org/10.1098/rstb.2012.0303

Anthony N.M., Johnson-Bawe M., JefFery K., Clifford S.L., Abernethy K.A., Tutin C.E., LAHM S.A., White L.J.T., UTLEY J.F., WiCKINGS E.J. \& BRUFORD M.W. (2007). The role of Pleistocene refugia and rivers in shaping gorilla genetic diversity in central Africa. Proceedings of the National Academy of Sciences 104: 20432-20436. https://doi.org/10.1073/pnas.0704816105

Anthony N.M., Atteke C., Bruford M.W., Dallmeier F., Freedman A., Hardy O., Ibrahim B., JefFery K.J., Johnson M., LAhM S.A., LePengue N., Lowenstein J.H., MAisels F., Mboumba J.-F., Mickala P., Morgan K., NTie S., Smith T.B., Sullivan J.P., Verheyen E. \& Gonder M.K. (2015). Evolution and conservation of Central African Biodiversity: priorities for future research and education in the Congo Basin and Gulf of Guinea. Biotropica 47: 6-17. https://doi.org/10.1111/btp.12188

Blom A. (2019a). Central Africa: Northern central part of the Democratic Republic of Congo. WWF. Available from https://www.worldwildlife.org/ecoregions/at0104 [accessed 17 August 2018].

Blom A. (2019b). Africa: Cameroon, Central African Republic, Gabon, and Republic of the Congo. World Wildlife Fund. Available from http://worldwildlife.org/ecoregions/at0126 [accessed 6 March 2019].

Blom A. \& Schipper J. (2019). Western Africa: Cameroon, Central African Republic, Gabon, and Republic of the Congo. World Wildlife Fund.

Available from https://www.worldwildlife.org/ecoregions/at0124 [accessed 17 August 2018].

Brooks T., Balmford A., Burgess N.D., Fjelds $\AA$ J., Hansen L.A., Moore J.L., Rahbek C. \& Williams P. (2001). Toward a blueprint for conservation in Africa. BioScience 51: 613-624. Available from http://www.bioone.org/doi/full/10.1641/0006-3568\%282001\%29051\%5B0613\%3ATA BFCI \%5D2.0.CO\%3B2 [accessed 25 March 2019].

CBD (2011). Strategic plan for Biodiversity 2011-2020 and the Aichi Targets. Convention on Biological Diversity, Québec. Available from https://www.cbd.int/sp/ [accessed 25 March 2019].

Chamberlain S. \& SALmon M. (2018). rredlist: IUCN Red List Client. Available from https://cran.rproject.org/web/packages/rredlist/rredlist.pdf [accessed 25 March 2019]. 
Chamberlain S., Barve V., Mcglinn D., Oldoni D., GefFert L. \& RAM K. (2018). rgbif: Interface to the Global "Biodiversity" Information Facility API.

Available from https://cran.r-project.org/web/packages/rgbif/rgbif.pdf [accessed 25 March 2019].

ChAo A. \& Jost L. (2012). Coverage-based rarefaction and extrapolation: standardizing samples by completeness rather than size. Ecology 93: 2533-2547. https://doi.org/10.1890/11-1952.1

Chao A., Chazdon R.L., Colwell R.K. \& Shen T.-J. (2005). A new statistical approach for assessing similarity of species composition with incidence and abundance data. Ecology Letters 8: 148-159. https://doi.org/10.1111/j.1461-0248.2004.00707.x

Chao A., Chazdon R.L., Colwell R.K. \& Shen T.J. (2006). Abundance-based similarity indices and their estimation when there are unseen species in samples. Biometrics 62: 361-371. https://doi.org/10.1111/j.1541-0420.2005.00489.x

Chao A., Gotelli N.J., Hsieh T.C., Sander E.L., Ma K.H., Colwell R.K. \& Ellison A.M. (2014). Rarefaction and extrapolation with Hill numbers: a framework for sampling and estimation in species diversity studies. Ecological Monographs 84: 45-67. https://doi.org/10.1890/13-0133.1

ChaO A., MA K.H. \& Hsien T.C. (2015). SpadeR: Species Prediction and Diversity Estimation with R. Available from https://cran.r-project.org/web/packages/SpadeR/index.html [accessed 25 March 2019].

CHAPMAN C.A.(1983). Speciation of tropical rainforest primates of Africa: insular biogeography. African Journal of Ecology 21: 297-308. https://doi.org/10.1111/j.1365-2028.1983.tb00329.x

COLYN M., GAUTIER-HION A. \& VERHEYEN W.(1991). A re-appraisal of palaeoenvironmental history in Central Africa: evidence for a major fluvial refuge in the Zaire Basin. Journal of Biogeography 18: 403-407. https://doi.org/10.2307/2845482

DE Klerk H.M., Crowe T.M., FJelds̊̊ J. \& Burgess N.D. (2002). Patterns of species richness and narrow endemism of terrestrial bird species in the Afrotropical region. Journal of Zoology 256: 327342. https://doi.org/10.1017/S0952836902000365

DE KLERK H.., FJELDSÅ J., BLYTH S. \& BURGESS N. (2004). Gaps in the protected area network for threatened Afrotropical birds. Biological Conservation 117: 529-537.

https://doi.org/10.1016/j.biocon.2003.09.006

DE Menocal P.B. (2004). African climate change and faunal evolution during the Pliocene-Pleistocene. Earth and Planetary Science Letters 220: 3-24. https://doi.org/10.1016/S0012-821X(04)00003-2

ERIKSSON J., HohmanN G., BOESCH C. \& Vigilant L. (2004). Rivers influence the population genetic structure of bonobos (Pan paniscus). Molecular Ecology 13: 3425-3435.

https://doi.org/10.1111/j.1365-294X.2004.02332.x

ESRI 2008. ArcGIS. Version 9.3. Environmental Systems Research Institute, Inc. Redlands, CA.

Fayolle A., Swaine M.D., Bastin J.-F., Bourland N., Comiskey J.A., Dauby G., Doucet J.-L., Gillet J.-F., Gourlet-Fleury S., Hardy O.J., Kirunda B., KouAmé F.N. \& Plumptre A.J. (2014). Patterns of tree species composition across tropical African forests. Journal of Biogeography 41: 2320 2331. https://doi.org/10.1111/jbi.12382

FINE P.V.A. (2015). Ecological and evolutionary drivers of geographic variation in species diversity. Annual Review of Ecology, Evolution and Systematics 46: 369-392.

https://doi.org/10.1146/annurev-ecolsys-112414-054102

FJELDSA J. \& LOVETT J.C. (1997). Geographical patterns of old and young species in African forest biota: The significance of specific montane areas as evolutionary centres. Biodiversity and Conservation 6: 325-346. https://doi.org/10.1023/A:1018356506390

Gambalemoke M., Mukinzi I., Amundala D., Gembu T., Kaswera K., Barrière P., Colyn M., Hutterer R., Kennis J., Leirs H., VANLinden B. \& Verheyen E. (2008). Microgeographical 
distribution of shrews (Mammalia, Soricidae) in the Congo River basin (Kisangani, DR Congo). Mammalia 72: 213-222. https://doi.org/10.1515/MAMM.2008.043

GASTON K.J.(2000). Global patterns in biodiversity.Nature 405:220-7.https://doi.org/10.1038/35012228

Gibson L., LeE T.M., KoH L.P., Brook B.W., GARDNer T.A., BARlow J., Peres C.A., BradshaW C.J., LAURANCE W.F., LOVEJOY T.E. \& SODHI N.S. (2011). Primary forests are irreplaceable for sustaining tropical biodiversity. Nature 478: 378-81. https://doi.org/10.1038/nature10425

Gotelli N.J. \& Colwell R.K. (2001). Quantifying biodiversity: procedures and pitfalls in the measurement and comparison of species richness. Ecology Letters 4: 379-391.

https://doi.org/10.1046/j.1461-0248.2001.00230.x

GRAHAM C.H., MORITZ C. \& WILliamS S.E. (2006). Habitat history improves prediction of biodiversity in rainforest fauna. Proceedings of the National Academy of Sciences 103: 632-636.

https://doi.org/10.1073/pnas.0505754103

GRYTNES J.-A. \& MCCAIN C.M. (2007). Elevational trends in biodiversity. In: Levin S.A. (ed.) Encyclopedia of Biodiversity: 1-8. Elsevier.

Hall B.P. \& Moreau R.E. (1970). An Atlas of Speciation in African Passerine Birds. Trustees of the British Museum (Natural History), London.

HARCOURT A.H. \& WOOD M.A. (2012). Rivers as barriers to primate distributions in Africa. International Journal of Primatology 33: 168-183. https://doi.org/10.1007/s10764-011-9558-Z

Hassanin A., Khouider S., Gembu G.C., Goodman S.M., Kadjo B., Nesi N., Pourrut X., NAKOUNÉ E. \& BONILlo C. (2015). The comparative phylogeography of fruit bats of the tribe Scotonycterini (Chiroptera, Pteropodidae) reveals cryptic species diversity related to African Pleistocene forest refugia. Comptes Rendus - Biologies 338: 197-211. https://doi.org/10.1016/j.crvi.2014.12.003

Hassanin A., Colombo R., Gembu G.C., Merle M., Tu V.T., Görföl T., AKawa P.M., Csorba G., KEARNEY T., MONADJEM A. \& ING R.K. (2018). Multilocus phylogeny and species delimitation within the genus Glauconycteris (Chiroptera, Vespertilionidae), with the description of a new bat species from the Tshopo Province of the Democratic Republic of the Congo. Journal of Zoological Systematics and Evolutionary Research 56: 1-22. https://doi.org/10.1111/jzs.12176

Hernandez P.A., Graham C.H., Master L.L. \& AlBert D.L. (2006). The effect of sample size and species characteristics on performance of different species distribution modeling methods. Ecography 29 : 773-785. https://doi.org/10.1111/j.0906-7590.2006.04700.x

HSIEH T.C., MA K.H. \& CHAO A. (2016). iNEXT: an R package for rarefaction and extrapolation of species diversity (Hill numbers).

Available from https://cran.r-project.org/web/packages/iNEXT/iNEXT.pdf [accessed 25 March 2019].

HUNTLEY J.W. \& VOELKER G. (2016). Cryptic diversity in Afro-tropical lowland forests: the systematics and biogeography of the avian genus Bleda. Molecular Phylogenetics and Evolution 99: 297-308. https://doi.org/10.1016/j.ympev.2016.04.002

HVilsom C., CARLSEn F., Heller R., JafFré N. \& Siegismund H.R. (2014). Contrasting demographic histories of the neighboring bonobo and chimpanzee. Primates 55: 101-112.

https://doi.org/10.1007/s10329-013-0373-3

IUCN (2018). The IUCN Red List of Threatened Species. Version 2018-2.

Available from http://www.iucnredlist.org [accessed 10 January 2019].

Jacquet F., Nicolas V., Colyn M., Kadjo B., Hutterer R., Decher J., AkPatou B., Cruaud C. \& DENYS C. (2014). Forest refugia and riverine barriers promote diversification in the West African pygmy shrew (Crocidura obscurior complex, Soricomorpha). Zoologica Scripta 43: 131-148. https://doi.org/10.1111/zsc.12039 
JETZ W. \& FINE P.V.A. (2012). Global gradients in vertebrate diversity predicted by historical areaproductivity dynamics and contemporary environment. PLoS Biology 10: e1001292.

https://doi.org/10.1371/journal.pbio.1001292

Katuala P.G.B., Kennis J., Nicolas V., Wendelen W., Hulselmans J., Verheyen E., Van Houtte N., DierckX T., Dudu A.M. \& Leirs H. (2008). The presence of Praomys, Lophuromys, and Deomys species (Muridae, Mammalia) in the forest blocks separated by the Congo River and its tributaries (Kisangani region, Democratic Republic of Congo). Mammalia 72: 223-228.

https://doi.org/10.1515/MAMM.2008.044

Kennis J., Nicolas V., Hulselmans J., Katuala P.G.B., Wendelen W., Verheyen E., Dudu A.M. \& LeIRS H. (2011). The impact of the Congo River and its tributaries on the rodent genus Praomys: speciation origin or range expansion limit? Zoological Journal of the Linnean Society 163: 983-1002. https://doi.org/10.1111/j.1096-3642.2011.00733.x

Lewin A., Feldman A., Bauer A.M., Belmaker J., Broadley D.G., Chirio L., Itescu Y., LeBreton M., Maza E., Meirte D., Nagy Z.T., Novosolov M., Roll U., Tallowin O., Trape J.F., VIDAN E. \& MEIRI S. (2016). Patterns of species richness, endemism and environmental gradients of African reptiles. Journal of Biogeography 43: 2380-2390. https://doi.org/10.1111/jbi.12848

LOUETTE M. (1992). Barriers, contact zones and subspeciation in central equatorial Africa. Bulletin B.O.C. Centenary Suppl 112A: 209-216.

Lovett J.C., Rudd S., TAPLin J. \&, Frimodt-Møller C. (2000). Patterns of plant diversity in Africa south of the Sahara and their implications for conservation management. Biodiversity and Conservation 9: 37-46. https://doi.org/10.1023/A:1008956529695

MALEY J. (1996). The African rain forest - main characteristics of changes in vegetation and climate from the Upper Cretaceous to the Quaternary. Proceedings of the Royal Society of Edinburgh, Section B, Biological Sciences 104: 31-73. https://doi.org/10.1017/S0269727000006114

Maley J., Doumenge C., Giresse P., Mahé G., Philippon N., Hubau W., Lokonda M.O., TShiBAmBA J.M. \& CHEPSTOW-LuSTY A. (2018). Late Holocene forest contraction and fragmentation in central Africa. Quaternary Research 89: 43-59. https://doi.org/10.1017/qua.2017.97

MYERs THOMPSON J.A. (2003). A model of the biogeographical journey from Proto-pan to Pan paniscus. Primates, Journal of Primatology 44: 191-7.

Available from http://europepmc.org/abstract/med/12687485 [accessed 25 March 2019].

Nicolas V., Verheyen E., Verheyen W.N., Hulselmans J., Dillen M., AKPatou B., Dudu A.M., Wendelen W. \& Colyn M. (2005). Systematics of African lowland rainforest Praomys (Rodentia, Muridae) based on molecular and craniometrical data. Zoological Journal of the Linnean Society 145: 539-553. https://doi.org/10.1111/j.1096-3642.2005.00196.x

Olayemi A., Nicolas V., Hulselmans J., Missoup A.D., Fichet-Calvet E., Amundala D., Dudu A.M., DierckX T., Wendelen W., Leirs H. \& Verheyen E. (2012). Taxonomy of the African giant pouched rats (Nesomyidae: Cricetomys): molecular and craniometric evidence support an unexpected high species diversity. Zoological Journal of the Linnean Society 165: 700-719.

https://doi.org/10.1111/j.1096-3642.2012.00823.x

Olson D.M., Dinerstein E., Wikramanayake E.D., Burgess N.D., Powell G.V.N., Underwood E.C., D’Amico J.A., Itoua I., Strand H.E., Morrison J.C., LOUCKS C.J., AllnUtT T.F., Ricketts T.H., Kura Y., LamoreuX J.F., Wettengel W.W., Hedao P. \& Kassem K.R. (2001). Terrestrial ecoregions of the world: a new map of life on earth. BioScience 51: 933-938. Available from https://bioone.org/journals/BioScience/volume-51/issue-11/0006-3568(2001)051[0933:TEOTWA]2.0. CO;2/Terrestrial-Ecoregions-of-the-World--A-New-Map-of/10.1641/0006-3568(2001)051 [0933:TEO TWA]2.0.CO;2.full [accessed 25 March 2019]. 
Parmentier I., Malhi Y., Senterre B., Whittaker R.J., Alonso A., Balinga M.P.B., BaKayoko A., Bongers F., Chatelain C., Comiskey J.A., Cortay R., Duuikouo Kamdem M.N., Doucet J.-L., Gautier L., Hawthorne W.D., Issembe Y.A., Kouamé F.N., KouKa L.A., Leal M.E., Lejoly J., Lewis S.L., Nusbaumer L., Parren M.P.E., Peh K.S.H., Phillips O.L., Sheil D., Sonké B., Sosef M.S.M., Sunderland T.C.H., Stropp J., Ter SteEge H., Swaine M.D., Tchouto M.G.P., VAN Gemerden B.S., Van Valkenburg J.L.C.H. \& WÖLL H. (2007). The odd man out? Might climate explain the lower tree alpha-diversity of African rain forests relative to Amazonian rain forests? Journal of Ecology 95: 1058-1071. https://doi.org/10.1111/j.1365-2745.2007.01273.x

PeEl M.C., Finlayson B.L. \& MCMahON T.A. (2007). Updated world map of the Köppen-Geiger climate classification. Hydrology and Earth System Sciences 11: 1633-1644.

https://doi.org/10.5194/hess-11-1633-2007

Phillips H.R.P., Newbold T. \& PuRvis A. (2017). Land-use effects on local biodiversity in tropical forests vary between continents. Biodiversity and Conservation 26: 2251-2270.

https://doi.org/10.1007/s10531-017-1356-2

Plana V. (2004. Mechanisms and tempo of evolution in the African Guineo-Congolian rainforest. Philosophical Transactions of the Royal Society B: Biological Sciences 359: 1585-1594. https://doi.org/10.1098/rstb.2004.1535

R CORE TEAM (2017). R: A language and environment for statistical computing. R Foundation for Statistical Computing, Vienna, Austria. Available from https://www.R-project.org/ [accessed 25 March 2019].

REDDY S. \& DÁvALOS L.M. (2003). Geographical sampling bias and its implications for conservation priorities in Africa. Journal of Biogeography 30: 1719-1727.

https://doi.org/10.1046/j.1365-2699.2003.00946.x

RICKLEFS R.E. (2006). Evolutionary diversification and the origin of the relationship of diversityenvironment. Ecology 87: 3-13.

Available from https://esajournals.onlinelibrary.wiley.com/doi/10.1890/0012-9658\%282006\%2987\% 5B3\%3AEDATOO\%5D2.0.CO\%3B2 [accessed 26 March 2019].

RickLEFS R.E., SCHWARZBACH A.E. \& RENNER S.S. (2006). Rate of lineage origin explains the diversity anomaly in the world's mangrove vegetation. The American Naturalist 168: 805-810. https://doi.org/10.1086/508711

Rowan J., Kamilar J.M., Beaudrot L. \& REed K.E. (2016). Strong influence of palaeoclimate on the structure of modern African mammal communities. Proceedings of the Royal Society B: Biological Sciences 283: 20161207. https://doi.org/10.1098/rspb.2016.1207

SaAtchi S.S., Harris N.L., Brown S., Lefsky M., Mitchard E.T.A., Salas W., Zutta B.R., BuermanN W., Lewis S.L., Hagen S., Petrova S., White L., Silman M. \& Morel A. (2011). Benchmark map of forest carbon stocks in tropical regions across three continents. Proceedings of the National Academy of Sciences of the United States of America 108: 9899-9904.

https://doi.org/10.1073/pnas.1019576108

SWENSON N.G., WeISER M.D., MAO L., NORMAND S., RodRÍGUEZ M.Á., Lin L., CAO M. \& SvenNing J.C. (2016). Constancy in functional space across a species richness anomaly. The American Naturalist 187: E83-E92. https://doi.org/10.1086/685083

TAKEMOTO H., KAWAMOTO Y. \& FURUICHI T. (2015). How did bonobos come to range south of the Congo River? Reconsideration of the divergence of Pan paniscus from other Pan populations. Evolutionary Anthropology 24: 170-184. https://doi.org/10.1002/evan.21456

Tosi A.J. (2008). Forest monkeys and Pleistocene refugia: a phylogeographic window onto the disjunct distribution of the Chlorocebus lhoesti species group. Zoological Journal of the Linnean Society 154: 408-418. https://doi.org/10.1111/j.1096-3642.2008.00419.x 
Tyukavina A., Hansen M.C., Potapov P., Parker D., OKPa C., Stehman S. V., Kommareddy I. \& TURUBANOVA S. (2018). Congo Basin forest loss dominated by increasing smallholder clearing. Science Advances 4: eaat2993. https://doi.org/10.1126/sciadv.aat2993

Willig M.R., KaUfMan D.M. \& STEVEnS R.D. (2003). Latitudinal gradients of biodiversity: pattern, process, scale, and synthesis. Annual Review of Ecology, Evolution and Systematics 34: 273-309. https://doi.org/10.1146/annurev.ecolsys.34.012103.144032

World WiLdLIFE Fund (2006). WildFinder: Online Database of Species Distributions. Ver. January 2006. Available from www.worldwildlife.org/WildFinder [accessed 7 January 2019].

Manuscript received: 6 December 2018

Manuscript accepted: 13 February 2019

Published on: 17 April 2019

Branch editor: Isa Schön 


\section{Supplementary material}

TABLE S1

The number of mammal species per family in each ecoregion based on the complete and habitat datasets of the GBIF and WWF database.

\begin{tabular}{|c|c|c|c|c|c|c|c|c|c|c|c|c|}
\hline & \multicolumn{6}{|c|}{ GBIF } & \multicolumn{6}{|c|}{ WWF } \\
\hline & \multicolumn{3}{|c|}{ Complete } & \multicolumn{3}{|c|}{ Habitat } & \multicolumn{3}{|c|}{ Complete } & \multicolumn{3}{|c|}{ Habitat } \\
\hline & CCLF & NELF & NWLF & CCLF & NELF & NWLF & CCLF & NELF & NWLF & CCLF & NELF & NWLF \\
\hline Anomaluridae & 2 & 5 & 3 & 2 & 5 & 3 & 3 & 5 & 6 & 3 & 5 & 6 \\
\hline Bovidae & 3 & 13 & 8 & 3 & 12 & 8 & 8 & 11 & 12 & 8 & 11 & 12 \\
\hline Canidae & 0 & 0 & 1 & 0 & 0 & 0 & 0 & 0 & 0 & 0 & 0 & 0 \\
\hline Cercopithecidae & 12 & 25 & 11 & 12 & 24 & 10 & 10 & 16 & 13 & 10 & 16 & 13 \\
\hline Chrysochloridae & 0 & 1 & 1 & 0 & 1 & 1 & 0 & 1 & 1 & 0 & 0 & 1 \\
\hline Elephantidae & 1 & 1 & 1 & 1 & 1 & 1 & 1 & 1 & 1 & 1 & 1 & 1 \\
\hline Emballonuridae & 0 & 2 & 2 & 0 & 2 & 2 & 2 & 2 & 2 & 2 & 2 & 2 \\
\hline Erinaceidae & 0 & 0 & 1 & 0 & 0 & 0 & 0 & 0 & 0 & 0 & 0 & 0 \\
\hline Felidae & 1 & 3 & 1 & 1 & 2 & 1 & 2 & 2 & 2 & 2 & 2 & 2 \\
\hline Galagidae & 1 & 3 & 3 & 1 & 3 & 3 & 2 & 3 & 5 & 2 & 3 & 5 \\
\hline Giraffidae & 0 & 1 & 0 & 0 & 1 & 0 & 1 & 1 & 0 & 1 & 1 & 0 \\
\hline Gliridae & 2 & 4 & 2 & 2 & 4 & 2 & 1 & 3 & 4 & 1 & 3 & 4 \\
\hline Herpestidae & 3 & 5 & 4 & 3 & 4 & 4 & 5 & 6 & 4 & 5 & 5 & 4 \\
\hline Hippopotamidae & 0 & 1 & 1 & 0 & 1 & 1 & 1 & 1 & 1 & 1 & 1 & 1 \\
\hline Hipposideridae & 2 & 5 & 7 & 2 & 5 & 7 & 4 & 7 & 5 & 4 & 7 & 5 \\
\hline Hominidae & 1 & 1 & 2 & 1 & 1 & 2 & 1 & 2 & 2 & 1 & 2 & 2 \\
\hline Hystricidae & 1 & 2 & 1 & 1 & 1 & 1 & 1 & 2 & 2 & 1 & 1 & 1 \\
\hline Leporidae & 0 & 1 & 0 & 0 & 0 & 0 & 0 & 0 & 0 & 0 & 0 & 0 \\
\hline Lorisidae & 0 & 3 & 3 & 0 & 3 & 3 & 1 & 1 & 2 & 1 & 1 & 2 \\
\hline Macroscelididae & 1 & 1 & 0 & 1 & 1 & 0 & 1 & 1 & 0 & 1 & 1 & 0 \\
\hline Manidae & 0 & 3 & 3 & 0 & 3 & 3 & 3 & 3 & 3 & 3 & 3 & 3 \\
\hline Megadermatidae & 0 & 0 & 1 & 0 & 0 & 0 & 1 & 1 & 1 & 0 & 0 & 0 \\
\hline Miniopteridae & 1 & 1 & 1 & 1 & 1 & 1 & 0 & 0 & 1 & 0 & 0 & 1 \\
\hline Molossidae & 0 & 10 & 7 & 0 & 8 & 7 & 4 & 9 & 9 & 3 & 7 & 8 \\
\hline Muridae & 25 & 43 & 33 & 17 & 22 & 20 & 14 & 26 & 21 & 11 & 19 & 17 \\
\hline Mustelidae & 2 & 2 & 3 & 1 & 1 & 1 & 3 & 3 & 3 & 2 & 2 & 2 \\
\hline Nandiniidae & 1 & 1 & 1 & 1 & 1 & 1 & 1 & 1 & 1 & 1 & 1 & 1 \\
\hline Nesomyidae & 3 & 7 & 4 & 2 & 2 & 2 & 1 & 3 & 3 & 1 & 2 & 3 \\
\hline Nycteridae & 1 & 5 & 6 & 1 & 4 & 6 & 5 & 7 & 9 & 5 & 6 & 7 \\
\hline Orycteropodidae & 0 & 0 & 0 & 0 & 0 & 0 & 1 & 1 & 0 & 1 & 1 & 0 \\
\hline Procaviidae & 0 & 2 & 1 & 0 & 2 & 1 & 1 & 1 & 1 & 1 & 1 & 1 \\
\hline Pteropodidae & 2 & 11 & 12 & 2 & 11 & 12 & 6 & 12 & 10 & 6 & 11 & 10 \\
\hline Rhinolophidae & 0 & 3 & 3 & 0 & 1 & 3 & 2 & 4 & 5 & 2 & 2 & 4 \\
\hline Sciuridae & 6 & 14 & 10 & 5 & 10 & 10 & 6 & 6 & 9 & 5 & 6 & 9 \\
\hline Soricidae & 3 & 21 & 19 & 2 & 16 & 17 & 1 & 20 & 24 & 1 & 16 & 19 \\
\hline Spalacidae & 1 & 1 & 0 & 0 & 0 & 0 & 0 & 0 & 0 & 0 & 0 & 0 \\
\hline Suidae & 0 & 2 & 2 & 0 & 1 & 2 & 1 & 2 & 2 & 1 & 2 & 2 \\
\hline Tenrecidae & 1 & 1 & 1 & 1 & 1 & 1 & 1 & 1 & 1 & 1 & 1 & 1 \\
\hline Thryonomyidae & 0 & 2 & 1 & 0 & 1 & 1 & 1 & 1 & 1 & 1 & 1 & 1 \\
\hline Tragulidae & 1 & 1 & 0 & 1 & 1 & 0 & 1 & 1 & 1 & 1 & 1 & 1 \\
\hline Vespertilionidae & 2 & 10 & 15 & 2 & 7 & 12 & 13 & 25 & 18 & 8 & 16 & 14 \\
\hline Viverridae & 3 & 7 & 5 & 3 & 7 & 5 & 4 & 6 & 5 & 4 & 6 & 5 \\
\hline Number of Species & 82 & 224 & 180 & 69 & 171 & 154 & 114 & 198 & 190 & 102 & 166 & 170 \\
\hline Number of Families & 26 & 38 & 36 & 25 & 36 & 33 & 36 & 37 & 35 & 35 & 35 & 34 \\
\hline
\end{tabular}


TABLE S2

The number of bird species per family in each ecoregion based on the complete and habitat datasets of the GBIF and WWF database.

\begin{tabular}{|c|c|c|c|c|c|c|c|c|c|c|c|c|}
\hline & \multicolumn{6}{|c|}{ GBIF } & \multicolumn{6}{|c|}{ WWF } \\
\hline & \multicolumn{3}{|c|}{ Complete } & \multicolumn{3}{|c|}{ Habitat } & \multicolumn{4}{|c|}{ Complete } & \multicolumn{2}{|c|}{ Habitat } \\
\hline & CCLF & NELF & NWLF & CCLF & NELF & NWLF & CCLF & NELF & NWLF & CCLF & NELF & NWLF \\
\hline Accipitridae & 14 & 33 & 22 & 9 & 21 & 15 & 21 & 33 & 24 & 15 & 20 & 17 \\
\hline Acrocephalidae & 0 & 8 & 5 & 0 & 2 & 1 & 2 & 6 & 6 & 0 & 1 & 2 \\
\hline Alaudidae & 1 & 2 & 1 & 0 & 0 & 0 & 0 & 2 & 0 & 0 & 0 & 0 \\
\hline Alcedinidae & 9 & 11 & 13 & 7 & 8 & 9 & 10 & 12 & 12 & 8 & 8 & 9 \\
\hline Anatidae & 2 & 6 & 4 & 1 & 2 & 2 & 4 & 17 & 7 & 1 & 2 & 2 \\
\hline Anhingidae & 1 & 1 & 1 & 1 & 1 & 1 & 1 & 1 & 1 & 1 & 1 & 1 \\
\hline Apodidae & 6 & 12 & 10 & 4 & 9 & 7 & 5 & 9 & 9 & 4 & 7 & 6 \\
\hline Ardeidae & 7 & 13 & 10 & 1 & 3 & 2 & 13 & 14 & 14 & 4 & 3 & 4 \\
\hline Bucerotidae & 7 & 9 & 8 & 7 & 9 & 8 & 6 & 7 & 7 & 6 & 7 & 7 \\
\hline Buphagidae & 0 & 0 & 1 & 0 & 0 & 1 & 0 & 0 & 1 & 0 & 0 & 1 \\
\hline Burhinidae & 0 & 0 & 2 & 0 & 0 & 0 & 0 & 1 & 1 & 0 & 0 & 0 \\
\hline Calyptomenidae & 1 & 2 & 1 & 1 & 2 & 1 & 1 & 3 & 3 & 1 & 3 & 3 \\
\hline Campephagidae & 2 & 8 & 3 & 2 & 6 & 3 & 1 & 4 & 5 & 1 & 4 & 5 \\
\hline Caprimulgidae & 3 & 4 & 7 & 2 & 2 & 3 & 4 & 9 & 11 & 2 & 4 & 4 \\
\hline Charadriidae & 2 & 9 & 7 & 0 & 0 & 0 & 7 & 7 & 6 & 0 & 0 & 0 \\
\hline Ciconiidae & 3 & 6 & 3 & 1 & 1 & 1 & 5 & 6 & 4 & 1 & 1 & 1 \\
\hline Cisticolidae & 12 & 34 & 24 & 7 & 22 & 16 & 12 & 27 & 30 & 8 & 18 & 17 \\
\hline Coliidae & 0 & 1 & 1 & 0 & 1 & 1 & 1 & 1 & 1 & 1 & 1 & 1 \\
\hline Columbidae & 8 & 13 & 11 & 7 & 11 & 7 & 7 & 12 & 11 & 7 & 8 & 9 \\
\hline Coraciidae & 3 & 4 & 4 & 3 & 4 & 4 & 2 & 5 & 2 & 2 & 4 & 2 \\
\hline Corvidae & 2 & 1 & 2 & 0 & 0 & 0 & 1 & 1 & 1 & 0 & 0 & 0 \\
\hline Cuculidae & 11 & 20 & 16 & 10 & 16 & 14 & 15 & 18 & 20 & 13 & 14 & 15 \\
\hline Dicruridae & 1 & 3 & 4 & 1 & 3 & 4 & 2 & 3 & 4 & 2 & 3 & 4 \\
\hline Emberizidae & 0 & 0 & 0 & 0 & 0 & 0 & 0 & 0 & 2 & 0 & 0 & 0 \\
\hline Estrildidae & 15 & 26 & 20 & 12 & 16 & 14 & 14 & 21 & 19 & 14 & 15 & 14 \\
\hline Falconidae & 0 & 5 & 6 & 0 & 1 & 0 & 2 & 3 & 3 & 0 & 0 & 0 \\
\hline Fringillidae & 1 & 7 & 2 & 0 & 1 & 0 & 0 & 0 & 1 & 0 & 0 & 1 \\
\hline Glareolidae & 1 & 3 & 2 & 0 & 0 & 0 & 4 & 3 & 2 & 0 & 0 & 0 \\
\hline Gruidae & 0 & 1 & 0 & 0 & 1 & 0 & 0 & 0 & 0 & 0 & 0 & 0 \\
\hline Heliornithidae & 1 & 1 & 1 & 1 & 1 & 1 & 1 & 1 & 1 & 1 & 1 & 1 \\
\hline Hirundinidae & 9 & 14 & 16 & 6 & 11 & 10 & 11 & 12 & 13 & 6 & 6 & 6 \\
\hline Hyliotidae & 0 & 2 & 2 & 0 & 1 & 1 & 1 & 1 & 2 & 1 & 0 & 1 \\
\hline Indicatoridae & 2 & 7 & 7 & 2 & 7 & 7 & 6 & 8 & 9 & 6 & 7 & 8 \\
\hline Jacanidae & 0 & 1 & 1 & 0 & 0 & 0 & 1 & 1 & 1 & 0 & 0 & 0 \\
\hline Laniidae & 1 & 5 & 2 & 0 & 1 & 1 & 0 & 2 & 3 & 0 & 2 & 2 \\
\hline Laridae & 0 & 3 & 4 & 0 & 0 & 0 & 3 & 4 & 3 & 0 & 0 & 0 \\
\hline Leiotrichidae & 0 & 2 & 0 & 0 & 2 & 0 & 0 & 2 & 2 & 0 & 2 & 1 \\
\hline Locustellidae & 1 & 4 & 2 & 0 & 0 & 0 & 1 & 3 & 3 & 0 & 0 & 0 \\
\hline Lybiidae & 9 & 12 & 13 & 9 & 12 & 12 & 9 & 10 & 13 & 9 & 10 & 13 \\
\hline Macrosphenidae & 0 & 6 & 5 & 0 & 4 & 4 & 4 & 6 & 6 & 3 & 4 & 4 \\
\hline Malaconotidae & 0 & 18 & 13 & 0 & 14 & 9 & 4 & 10 & 11 & 4 & 7 & 8 \\
\hline Meropidae & 7 & 11 & 9 & 5 & 6 & 6 & 6 & 9 & 8 & 5 & 5 & 6 \\
\hline Modulatricidae & 0 & 1 & 0 & 0 & 0 & 0 & 0 & 0 & 0 & 0 & 0 & 0 \\
\hline Monarchidae & 5 & 7 & 5 & 5 & 7 & 5 & 4 & 5 & 4 & 4 & 5 & 4 \\
\hline Motacillidae & 4 & 13 & 9 & 0 & 1 & 0 & 4 & 7 & 9 & 1 & 1 & 1 \\
\hline Muscicapidae & 11 & 43 & 31 & 9 & 25 & 21 & 13 & 34 & 32 & 11 & 22 & 22 \\
\hline Musophagidae & 5 & 4 & 5 & 4 & 2 & 4 & 2 & 3 & 3 & 2 & 3 & 3 \\
\hline Nectariniidae & 13 & 29 & 20 & 11 & 20 & 17 & 17 & 19 & 17 & 16 & 17 & 15 \\
\hline
\end{tabular}




\begin{tabular}{|c|c|c|c|c|c|c|c|c|c|c|c|c|}
\hline & \multicolumn{6}{|c|}{ GBIF } & \multicolumn{6}{|c|}{$\overline{W W F}$} \\
\hline & \multicolumn{4}{|c|}{ Complete } & \multicolumn{2}{|c|}{ Habitat } & \multicolumn{3}{|c|}{ Complete } & \multicolumn{3}{|c|}{ Habitat } \\
\hline & CCLF & NELF & NWLF & CCLF & NELF & NWLF & CCLF & NELF I & NWLF & CCLF & NELF & NWLF \\
\hline Otididae & 2 & 1 & 2 & 0 & 0 & 0 & 0 & 1 & 0 & 0 & 0 & 0 \\
\hline Pandionidae & 0 & 1 & 1 & 0 & 0 & 0 & 1 & 1 & 1 & 0 & 0 & 0 \\
\hline Paridae & 0 & 3 & 2 & 0 & 1 & 1 & 1 & 1 & 1 & 1 & 1 & 1 \\
\hline Parulidae & 0 & 1 & 1 & 0 & 1 & 1 & 0 & 0 & 0 & 0 & 0 & 0 \\
\hline Passeridae & 1 & 2 & 1 & 0 & 0 & 0 & 1 & 1 & 1 & 0 & 0 & 0 \\
\hline Pelecanidae & 0 & 0 & 0 & 0 & 0 & 0 & 2 & 1 & 2 & 0 & 0 & 0 \\
\hline Pellorneidae & 1 & 5 & 3 & 1 & 4 & 3 & 3 & 3 & 3 & 3 & 3 & 3 \\
\hline Phalacrocoracidae & 1 & 1 & 1 & 1 & 1 & 1 & 1 & 1 & 1 & 1 & 1 & 1 \\
\hline Phasianidae & 2 & 9 & 5 & 2 & 5 & 3 & 2 & 6 & 5 & 2 & 4 & 4 \\
\hline Phoeniculidae & 0 & 3 & 1 & 0 & 2 & 1 & 0 & 3 & 2 & 0 & 3 & 2 \\
\hline Phylloscopidae & 0 & 4 & 2 & 0 & 3 & 2 & 2 & 3 & 3 & 2 & 3 & 3 \\
\hline Picathartidae & 0 & 0 & 1 & 0 & 0 & 1 & 0 & 0 & 0 & 0 & 0 & 0 \\
\hline Picidae & 5 & 11 & 11 & 5 & 10 & 10 & 7 & 13 & 12 & 7 & 12 & 10 \\
\hline Pittidae & 0 & 1 & 1 & 0 & 1 & 1 & 1 & 2 & 2 & 1 & 2 & 2 \\
\hline Platysteiridae & 3 & 11 & 10 & 3 & 9 & 8 & 3 & 8 & 10 & 3 & 8 & 8 \\
\hline Ploceidae & 13 & 39 & 29 & 9 & 23 & 21 & 14 & 27 & 21 & 13 & 20 & 17 \\
\hline Pluvianidae & 0 & 1 & 1 & 0 & 0 & 0 & 0 & 0 & 0 & 0 & 0 & 0 \\
\hline Podicipedidae & 0 & 1 & 1 & 0 & 0 & 0 & 1 & 1 & 1 & 0 & 0 & 0 \\
\hline Psittacidae & 2 & 4 & 3 & 2 & 4 & 3 & 2 & 5 & 4 & 2 & 4 & 4 \\
\hline Pycnonotidae & 13 & 33 & 26 & 13 & 31 & 25 & 18 & 26 & 25 & 18 & 25 & 24 \\
\hline Rallidae & 4 & 13 & 10 & 2 & 4 & 3 & 7 & 10 & 11 & 3 & 3 & 4 \\
\hline Remizidae & 0 & 2 & 1 & 0 & 1 & 1 & 0 & 1 & 2 & 0 & 1 & 1 \\
\hline Sagittariidae & 0 & 0 & 1 & 0 & 0 & 0 & 0 & 1 & 0 & 0 & 0 & 0 \\
\hline Scolopacidae & 2 & 10 & 6 & 0 & 0 & 0 & 11 & 15 & 12 & 0 & 0 & 0 \\
\hline Scopidae & 1 & 1 & 1 & 0 & 0 & 0 & 1 & 1 & 1 & 0 & 0 & 0 \\
\hline Scotocercidae & 2 & 4 & 3 & 2 & 4 & 3 & 2 & 3 & 3 & 2 & 3 & 3 \\
\hline Sittidae & 0 & 0 & 1 & 0 & 0 & 0 & 0 & 0 & 0 & 0 & 0 & 0 \\
\hline Stenostiridae & 0 & 3 & 2 & 0 & 3 & 2 & 2 & 2 & 2 & 2 & 2 & 2 \\
\hline Strigidae & 4 & 10 & 7 & 4 & 9 & 6 & 9 & 14 & 12 & 9 & 12 & 11 \\
\hline Sturnidae & 5 & 10 & 7 & 4 & 5 & 4 & 3 & 4 & 6 & 3 & 4 & 4 \\
\hline Sylviidae & 0 & 3 & 1 & 0 & 0 & 0 & 1 & 1 & 1 & 0 & 0 & 0 \\
\hline Threskiornithidae & 1 & 2 & 3 & 0 & 1 & 2 & 4 & 6 & 6 & 1 & 2 & 2 \\
\hline Trogonidae & 1 & 3 & 2 & 1 & 3 & 2 & 1 & 2 & 2 & 1 & 2 & 2 \\
\hline Turdidae & 2 & 11 & 7 & 2 & 7 & 5 & 4 & 7 & 6 & 3 & 6 & 5 \\
\hline Turnicidae & 0 & 1 & 1 & 0 & 0 & 0 & 1 & 1 & 2 & 0 & 0 & 0 \\
\hline Tytonidae & 0 & 0 & 1 & 0 & 0 & 0 & 0 & 1 & 0 & 0 & 0 & 0 \\
\hline Upupidae & 0 & 1 & 0 & 0 & 0 & 0 & 0 & 1 & 0 & 0 & 0 & 0 \\
\hline Vangidae & 3 & 5 & 5 & 3 & 4 & 4 & 3 & 3 & 3 & 3 & 3 & 3 \\
\hline Viduidae & 1 & 3 & 3 & 0 & 1 & 0 & 1 & 1 & 2 & 0 & 0 & 0 \\
\hline Zosteropidae & 0 & 1 & 1 & 0 & 1 & 1 & 0 & 1 & 1 & 0 & 1 & 1 \\
\hline Number of species & 253 & 652 & 511 & 185 & 403 & 334 & 342 & 551 & 522 & 245 & 350 & 344 \\
\hline Number of families & 58 & 84 & 85 & 44 & 66 & 61 & 71 & 83 & 80 & 54 & 60 & 62 \\
\hline
\end{tabular}


TABLE S3

The number of reptile species per family in each ecoregion based on the GBIF and WWF databases.

\begin{tabular}{lccc|ccc}
\hline & & GBIF & & & WWF & \\
& CCLF & NELF & NWLF & CCLF & NELF & NWLF \\
\hline Agamidae & 2 & 3 & 4 & 0 & 3 & 1 \\
Amphisbaenidae & 0 & 0 & 0 & 2 & 0 & 0 \\
Anguidae & 0 & 0 & 1 & 0 & 0 & 0 \\
Atractaspididae & 0 & 0 & 0 & 9 & 12 & 15 \\
Boidae & 0 & 1 & 1 & 2 & 2 & 2 \\
Chamaeleonidae & 0 & 10 & 6 & 1 & 7 & 4 \\
Colubridae & 3 & 22 & 18 & 36 & 46 & 44 \\
Cordylidae & 0 & 0 & 1 & 0 & 0 & 0 \\
Crocodylidae & 2 & 3 & 2 & 2 & 2 & 2 \\
Elapidae & 2 & 5 & 5 & 5 & 4 & 5 \\
Gekkonidae & 2 & 8 & 7 & 0 & 6 & 8 \\
Geoemydidae & 0 & 0 & 1 & 0 & 0 & 0 \\
Lacertidae & 0 & 2 & 2 & 3 & 5 & 4 \\
Lamprophiidae & 2 & 21 & 15 & 0 & 0 & 0 \\
Leptotyphlopidae & 0 & 0 & 0 & 0 & 1 & 3 \\
Natricidae & 0 & 2 & 4 & 0 & 0 & 0 \\
Pelomedusidae & 0 & 4 & 1 & 1 & 2 & 2 \\
Phyllodactylidae & 0 & 0 & 1 & 0 & 0 & 0 \\
Pythonidae & 0 & 1 & 1 & 0 & 0 & 0 \\
Scincidae & 1 & 9 & 11 & 6 & 11 & 15 \\
Testudinidae & 1 & 1 & 3 & 1 & 3 & 2 \\
Trionychidae & 0 & 1 & 0 & 0 & 1 & 1 \\
Typhlopidae & 1 & 3 & 4 & 3 & 5 & 8 \\
Varanidae & 1 & 1 & 1 & 1 & 1 & 1 \\
Viperidae & 2 & 7 & 5 & 5 & 6 & 6 \\
\hline Number of species & 19 & 104 & 94 & 77 & 117 & 123 \\
Number of families & 11 & 18 & 21 & 14 & 17 & 17 \\
\hline
\end{tabular}



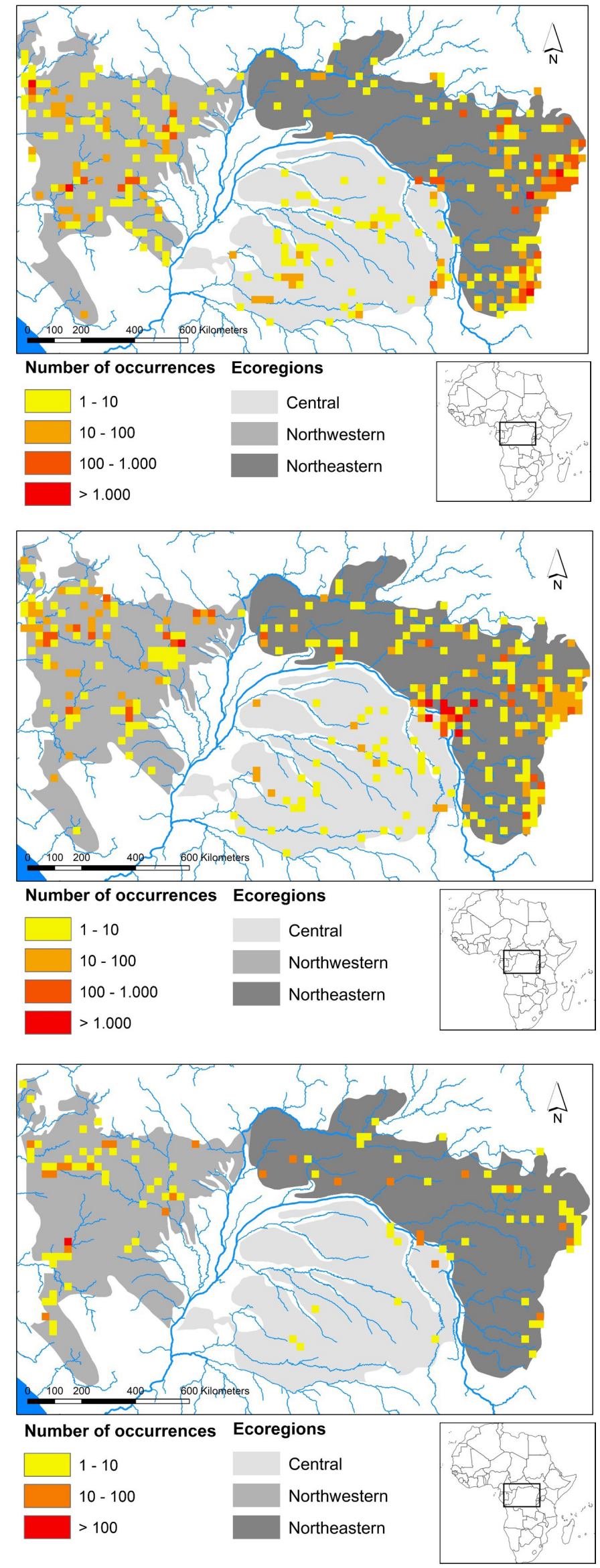

FIGURE S1 - Location and intensity of GBIF samples are clustered along rivers and major cities (top $=$ birds; middle $=$ mammals; bottom $=$ reptiles). 